Marzena Banach

Poznan University of Technology

\title{
USE OF INTELLIGENT HYBRID SOLUTIONS IN SUSTAINABLE PUBLIC TRANSPORTATION SYSTEM FOR THE NET OF SMALL CITIES
}

\begin{abstract}
The paper presents a concept of intelligent hybrid public transport for small satellite towns of larger agglomerations functioning in Polish reality. In Poland, there is observed a phenomenon of everyday commuting to work and schools from towns and cities distant up to several dozen kilometers from the metropolitan city. Often, inflexible and relatively expensive public transport causes, that own car is often used. This translates into increased traffic in the central city. An additional problem is in many cases the lack of adequate parking at the local railway station, allowing for leaving own car. The proposed solution to improve the flexibility of suburban public transport is to use autonomous vehicles in the near future, but locally in areas surrounding railway stations. Such vehicles would not require parking, while being a mean of transport "on demand", just like own car. An exemplary analysis for Polish communes is shown based on the Voronoi diagram, illustrating the extent of the areas from which the inhabitants commute to the local railway station.
\end{abstract}

Keywords: sustainable development, hybrid public transport, intelligent transportation system, small towns

\section{Streszczenie}

\section{Zastosowanie inteligentnych rozwiązań hybrydowych w zrównoważonym publicznym systemie transportowym dla sieci małych miast}

W artykule przedstawiono koncepcję inteligentnego hybrydowego transportu publicznego dla małych miejscowości satelickich większych aglomeracji funkcjonujących w realiach polskich. W Polsce występuje zjawisko powszechnego codziennego dojeżdżania do pracy oraz do szkół z miejscowości oddalonych nawet o kilkadziesiąt kilometrów od miasta metropolitalnego. Nieelastyczny i relatywnie drogi transport publiczny powoduje, że często wybieranym środkiem transportu jest własny samochód. Przekłada się to na zwiększony 
ruch drogowy w mieście centralnym. Dodatkowym problemem, w wielu przypadkach, jest brak odpowiedniego parkingu przy lokalnej stacji kolejowej, umożliwiającego pozostawienie własnego samochodu. Zaproponowane rozwiązanie w celu poprawy elastyczności podmiejskiego transportu publicznego polega na zastosowaniu w nim w niedalekiej przyszłości pojazdów autonomicznych, ale lokalnie, na obszarach w otoczeniu stacji kolejowych. Takie pojazdy nie wymagałyby parkingów, będąc jednocześnie środkiem transportu „na żądanie”, podobnie jak własny samochód. Przykładową analizę dla polskich gmin pokazano na podstawie siatek Voronoia, ilustrujących rozległość obszarów, z których mieszkańcy dojeżdżają do lokalnej stacji kolejowej.

Słowa kluczowe: zrównoważony rozwój, hybrydowy transport publiczny, inteligentny system transportowy, małe miejscowości

\section{Introduction - definition of a problem}

The migration of people, observed for many years, is increasingly intensifying towards larger urban agglomerations. As of today, more than $50 \%$ of the world's population lives in cities [ISO 37120, 2017], and according to forecasts for the next 30 years, in highly urbanized areas, it will be even close to $70 \%$ population, if the pace of migration is maintained. The majority of them is small, which in Poland usually means maximum 20,000 citizens [Szymańska, Grzelak-Kostuls$\mathrm{ka}, 2005]$. It is worth to consider how these predictions may impact the quality of life of urban residents, as well as spatial development. For instance, when it comes to transport, the problem should be highlighted of the capacity of roads, the crowding of internal roads and the resulting difficulties.

\section{I.I. Road and urban conditions in Poland}

In Poland, a rapid increase in the number of cars, and thus an intensified crowding of circulation routes is additionally due to a substantial import of used cars from European Union countries after Poland's accession to the EU. Additionally, in the case of many small towns, an underdevelopment of urban-forming factors is identified [Wałkuska, 2003], especially related to the service of the population, and hence to the transportation infrastructure. Therefore, small towns in Poland frequently become satellites of bigger cities, in terms of, for example, economic and educational interests. A phenomenon that intensified this process was the collapse, after the political transformation in Poland in the 1990s, many local workplaces that did not withstand competition. As a result, there is often a shortage of sufficient jobs in smaller towns, and these that are still available are usually much less paid than those in larger cities. The natural resultant tendency in this case is the migration of people to these cities. This, however, causes an increase in property prices (in major Polish cities even by several dozen $\%$ in recent years) [Wyszomirski, 2007]. It starts to create a barrier, that causes, that many villagers more willingly decide to live away from the central city, even at a considerable 
distance, and commute to work every day. The consequence is the growing demand for transport.

Additionally, as the lifestyle of residents changes, their needs change also in the mobility. The cost of travel, its duration and the traveling comfort associated with it, are becoming more and more important. In this situation, when choosing the transportation means indisputably still "wins" one's own car. Quite often, the public transport is less convenient, sometimes unpunctual, and therefore it is less frequently chosen, especially by the inhabitants of satellite towns.

Unfortunately, public transport, serving cities located at a greater distance from the metropolitan agglomeration, absorbs much more financial resources than the organization of transport in the towns themselves. This is associated with larger road sections between collection points and, in addition, with a lower population density, and thus less flexible timetable. Hence using own, independent means of transport is just faster and more convenient. Unfortunately, residents of nearby towns contribute in this way in the problem of increased traffic and jams in the streets of central city.

This issue may be solved in two general ways. One of them is an appropriate urban planning that takes into consideration the needs of urban users - a sustainable development which, among others, promotes cities with more compact buildings, thanks to which daily distances are reduced [Lehmann, 2010]. According to the Author, however, this solution requires large changes in planning (difficult or impossible with existing buildings) and thus large financial outlays. It should also be noted, that this solution is not an answer to the needs of the inhabitants of satellite towns. Modifying the urban infrastructure, in order to make the room needed to accommodate the growing traffic, has a negative impact on the appearance and functionality of the urban areas, including the problem of pollutions and noise.

Another solution, more effective and cheaper in the long-term perspective, may be an increase of a real competitiveness of public transport, especially that serving the connection of satellite towns with the central city. In practice, it usually wins this mode of transport, which is cheaper, provides a shorter travel time and at the same time is more convenient. For example, a relatively cheap and thus widely used fuel in Poland is liquid petroleum gas (LPG). The resultant cost of driving own car (in the order of 5-10 eurocent $/ \mathrm{km}$ ) is often lower, than the cost of traveling by public transport. Often there is also a lack of sufficient parking area at railway stations, so that residents can quickly change to the train.

The described problem is more and more frequently noticed by local authorities in Poland. As an example, one can refer to the Pobiedziska community, distant from the Poznań city by about $25 \mathrm{~km}$ [Metropolia Poznań, 2018; Pobiedziska. Moc inspiracji, 2018]. In 2017, a meeting of local authorities with representatives of the Poznan authorities was held. They discussed a common transport strategy, just due to the problems described above. This shows, that the problems of congestion in big cities start to be solved together, which is worth emphasizing here. One of the questions asked was: "Car or train?", i.e. how to encourage residents to give up their own vehicle in favor of travel by 
train, thus limiting the number of cars on the roads in Poznan. However, while the train allows to quickly reach Poznań, the problem is how to get quickly to one of the local railway stations around Poznań. In case of the described Pobiedziska community, this problem was solved temporarily. Residents were offered several pilot bus lines, free of charge, but so far only until the end of 2018. This shows, that the problem of lack of public transport competitiveness is seen in reducing transport prices.

The described approach is a step in the right direction, however, it is worth to pay attention to two issues: (a) the cost of maintaining bus lines, including the cost of drivers' salaries, (b) flexibility in such aspects as bus frequencies, routes, location of stops and the travel times themselves, time to wait for a change, etc. Regular bus lines are still not an "on demand" transportation mean. The passenger must adapt their plans to the bus schedule, reach the bus stop (the problem of the first and last kilometer) [Dąbek, 2013], accept a potential delay, etc. These elements impact the competitiveness of public transport.

\section{I.2. Towards more flexible hybrid public transport}

The examples provided above show, that it is necessary to look for other solutions, which will further reduce the cost of travel, while increasing its flexibility. In this context, an interesting solution has been found in St. Albert - a city in Canada in province of Alberta. In this city, on Sunday local buses operate in the "on demand" mode. Passengers at given hours call the driver, informing him about the place from which they want to go and the time they want to travel to Edmonton (central city of the agglomeration). The driver arranges the route dynamically in such a way, as to gather all passengers and bring them to the interchange point, from which buses depart towards Edmonton. At the same time, he picks up passengers who have returned from Edmonton within St-Albert [Weekend Service, 2008-2019] Sunday, in this over 65,000 habitants city, due to the smaller number of passengers on that day, to some extent is a model of communities with lower population densities. In St-Albert, communication on this day is served only by three buses, which is possible thanks to flexible routes, adapted to particular passengers.

The St-Albert model in the future may be developed towards even greater flexibility. The solution here may be a larger number of vehicles (autonomous), smaller than a typical bus, with timetables and to some extent routes dynamically adapted to current needs of the residents of the community. Taking this into account, the main thesis of this work may be defined as follows:

An appropriate use of autonomous vehicles in the near future, as one of the components of the public hybrid transportation system may substantially improve the flexibility of such transport, especially in the context of smaller satellite towns in larger agglomerations. 
The word "appropriate" is here important. The use of vehicles of this type should be economically justified, so that it has a real impact on the competitiveness of public transport. It must be also safe, so that residents want to use them.

In recent years, many automotive companies in the world are carrying out advanced works towards introducing autonomous vehicles to the market [Domański, Kozłowski, 2017]. Vehicles of this type, on certain conditions, may become part of the so-called intelligent transportation system (ITS), including hybrid public transport. Several aspects are important here.

One of them is a profitability of the transport based on autonomous vehicles, especially in the case of satellite towns, that alone do not have a sufficient budget. It is worth emphasizing, that it is a problem for the whole agglomeration. It is in the interest of the central cities of the agglomerations, that the inhabitants of satellite villages do not commute to work or schools with their own cars. Thus, one can expect, that the larger city will participate in these costs, as in discussed Pobiedziska example above.

Such cars will initially be expensive, which is due to large investments [Owczarzak, Żak, 2015]. However, one can expect, that as they become more popular, their cost, like many other technologies, will gradually decrease. If today the average municipality can afford to buy buses and pay for their drivers, it can be assumed, that the same municipality will be able to afford some number of smaller autonomous vehicles.

Moreover, the profitability should be considered in a broader context. Buying even several hundred autonomous buses for the overall agglomeration may be cheaper than modifying the urban and road infrastructure in the cities. Reducing the problem of pollution in cities is a separate asset here.

Another issue is the safety of new autonomous technologies. Such cars must move unmistakably in a challenging environment. An example of possible problems to solve is the appearance of road signs that in Poland, for example, often do not meet the required standards (see Illustration 1). Their visibility may be limited, they are located at wrong altitudes, etc.

The concept of using such vehicles in public hybrid transport for satellite cities, proposed in this work, takes this problem into account. One of possible options relies on allowing the operation of such vehicles at limited areas or in selected and appropriately prepared road segments. In less densely populated areas, where traffic is smaller, the surroundings of such vehicles may pose a smaller challenge for their control systems than, for example, in crowded centers of larger cities with a larger number of moving objects. An intelligent urban infrastructure, understood here as a vehicle-to-infrastructure (V2I) communication system, will be a key element [Jia, Ngoduy, 2016]. For example, road signs may be equipped with V2I devices, providing important data to passing vehicles.

Hybrid public transportation system is a subject of the investigations carried out over the world today, including Poland. The aim is to raise the competitiveness of such transport that is the guiding principle of the presented work. One of typical solutions is a unification of timetables and tariffs for particular transportation 

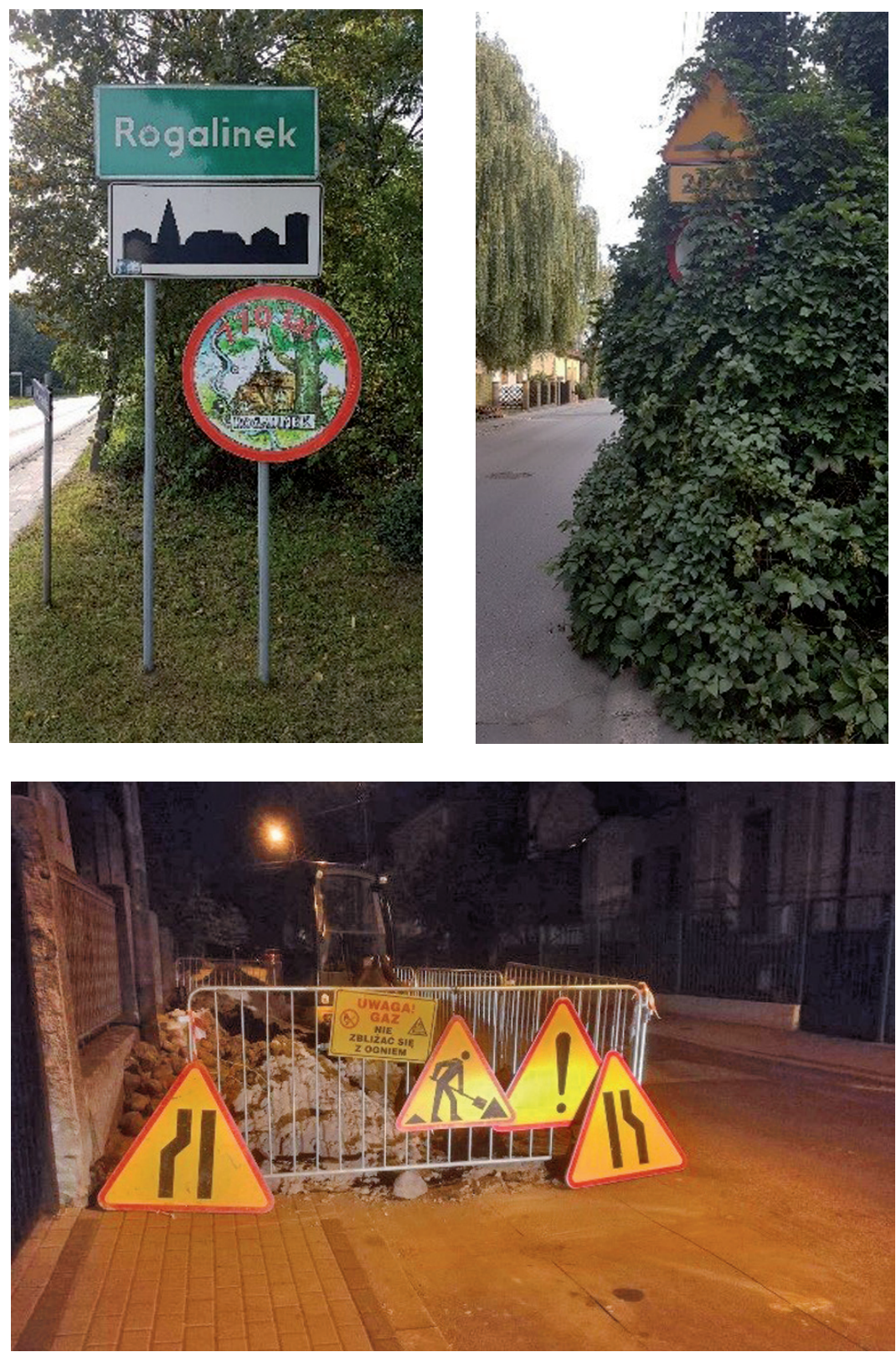

Illustration 1. Example situations on polish roads - not typical appearance of road signs, that may be a challenge for future autonomous cars

Source: author's own work. 
means, for example the BTK system (Bus - Tram - Railway, "kolej" in Polish), discussed in more detail in next Section [Bus, tramwaj, kolej, 2018].

One of the crucial elements of the hybrid transport is an appropriate system of free parking lots near railway stations, aimed at encouraging for changing own cars into rail. In Polish conditions, however, specific circumstances need to be taken into account, such as the lack of sufficiently large parking lots at railway stations. In this situation, autonomous vehicles could be used to transport passengers to the local station directly from their place of residence, however, an issue here are distances to the stations. It is discussed in Section 3 of this work. Another option is to locate the interchange car parking at some distance from the stations and to ensure transport to the station by means of such vehicles.

The second option is interesting, as it can further narrow the area on which such vehicles operate. It would reduce the costs of the intelligent road infrastructure based on the V2I system, as well as the duration of the "empty" courses. Similar solutions are used, for example, at Heathrow airport in Great Britain, where, on short distances, between terminals, transport is based on autonomous vehicles (PODS system) [Holdsword, 2018].

\section{I.3. Intelligent transportation system}

Essentially, the main goal of the ITS system is to optimize the routes of the vehicles to ensure their smooth traffic, that should eliminate or significantly reduce the noise, emissions of harmful substances and crowds on the streets. This system, through the possible elimination of driving errors, is also hoped to improve road safety.

One of the solutions is an intelligent traffic control system, applied in larger Polish cities, e.g. in Tricity (Gdańsk, Sopot, Gdynia), [GDDKiA, 2015; Korolczuk, 2015], Białystok [Wschodzący Białystok, 2018], and Bydgoszcz [Bydgoszcz, 2018]. ITS, however, may also include solutions related to public transport. In Bydgoszcz, for example, a new tram route to Fordon - part of the investment in the local ITS - took over the traffic previously served by buses. Assumed improvement rates were at the level of about $6 \%$ for personal transport, while in some situations the real improvement is even around 30\%. Similarly, better than planned results were achieved for public transport (13\% for initial assumptions of $8 \%$ ) [Bydgoszcz, 2018].

The use of autonomous vehicles is also considered in the context of the optimization of car traffic on city streets, and on the city space, e.g. less need for parking lots. Kinder Baumgardner says that: "the total number of cars will be reduced and that will free up a great deal of space in urban centers that is currently devoted to garages". "The places where people used to park will be occupied by small businesses and stores" [BBVA, 2018].

However, not all agree with such opinions. The traffic control system described above, may to some extent have paradoxically an adverse effect on public transport. Smaller traffic jams, resulting in shorter travel times, encourage to drive 
own car. Note a greater improvement in indicators for car traffic than for public transport in the example of Bydgoszcz city. Historical data show, that road facilitation usually led to an increase in demand for the use of own cars [Duranton, Turner, 2016]. A more comfortable travel with autonomous cars may cause more demand for traveling, leading to the traffic-jams again, to more urbanization and more sprawl [Venkatesh Prasad, Hodges, Noble, 2016]. Taking such opinions into account, the ITS should be developed toward a larger support for the public transport, especially in smaller towns, as proposed in this work.

\section{I.4. Research methodology}

The motivation behind this work was self-observation of the problem of daily commuting to work and schools from smaller towns, where there is no parking at the local railway station. The Pobiedziska community partially solved this problem by building a car parking near local railway station. However, the studies performed by the author for the surroundings of Poznan city show, that in many cases it is not possible to build the parking directly at the railway station, due to the lack of free lot. Such situation is, for example, in Puszczykowo, Dopiewo, Palędzie. As proposed in this work, the solution for such railway stations could be "on demand" transportation means that do not require parking. Hence the idea of local public transport based in the future on autonomous vehicles.

An issue here are maximum distances from a given railway station at which autonomous vehicles could operate. For this reason, studies based on the geographical distribution of satellite towns around particular local stations in the vicinity of the Poznań city were performed. They have been illustrated by Voronoi diagrams adapted to visualize a division of the Poznań environment into zones of influence of particular stations [Motaa, Takanob, Tacob, 2014]. Details are provided in Section 3.3.

\section{State-of-the art study: Modern solutions for transportation in cities}

The main factors determining the choice of a given transportation mean include its cost, time of travel, and comfort. The hierarchy of validity of these criteria depends on the time of travel, the purpose of the journey, and also the nature of the trip (whether it is routine, daily or occasional).

Unfortunately, in larger agglomerations in Poland, it can be seen that in many cases the travel time by public transport is even 2-3 times longer, than when using a personal car. Thus, one can observe works towards improvement of the public transport offer (punctuality, reliability). Selected state-of-the-art solutions, both those currently in use and those, that have a chance to become popular in a short time, are presented below. 


\section{I. Integrated railway and municipal transportation}

Such a solution works in many cities. In Poznań, for example, the BTK (Bus-Tramway-Railway) ticket is valid on trains within a radius of $50 \mathrm{~km}$ from Poznań, as well as in public transport (zones A-G) (see Illustration 2) [Bus, tramwaj, kolej, 2018; Koleje Wielkopolskie, 2018]. This solution is more cost-effective, than when purchasing monthly train and city tickets, separately. However, the price is still relatively high. For adults (without discount) the price in the $\mathrm{A}+\mathrm{B}$ and $\mathrm{A}+\mathrm{B}+\mathrm{C}$ zones is $186 \mathrm{PLN}$ and $274 \mathrm{PLN} /$ month, respectively, while one person uses one ticket. In zone $\mathrm{C}$, there are villages where getting to the city by car is still much cheaper.

\subsection{City bicycle}

In the context of hybrid transport, a city bike may play an important role. In some Polish cities, it is integrated in price with public transport, providing discounts for monthly ticket holders. In Poznan, for example, for holders of valid monthly ticket, the price per hour of bicycle use is 1 PLN (normally 2 PLN) and the period of free use of the bicycle is extended by $50 \%$. It offers several advantages. It is often a faster than the public transport, as it allows to bypass traffic jams. However, there are also some functionality limitations. One rented bicycle $=1$ traveler, which does not solve the problem of families. Other problem is the weather that in Poland is often rainy, especially in autumn and winter.

As shown in Illustration 3, in some situations the bike can become an efficient element of the hybrid transport. The presented case study assumes access by train to one of the intermediate railway stations within Poznań (Poznań Wschód in this example), for example from described Pobiedziska community. Note a situation shown in Illustration 3 (a), in which a small distance covered by walking takes up to 7 minutes, i.e. even $20-30 \%$ of total travel time inside the city. Making a small route section $(1.3 \mathrm{~km}-$ c. 5 minutes) by bike, one can shorten the journey even by more than ten minutes, which translates into the competitiveness (flexibility) of public transport. To facilitate it, bike renting spots should be located close to tram or bus stops. In the case of satellite villages, a similar "on demand" solution operating at short distances could be low-cost autonomous cars or buses.

\subsection{Free municipal transportation}

Reducing the cost of travel by public transport is one of the solutions toward the competitiveness of public transport, for example in Pobiedziska commune, described above. Such solutions aim at reducing the number of cars driving in the city, thus reducing noise, exhaust gases and increasing the capacity of congested transportation arteries. Even so, private transport seems to be still faster and more convenient. 


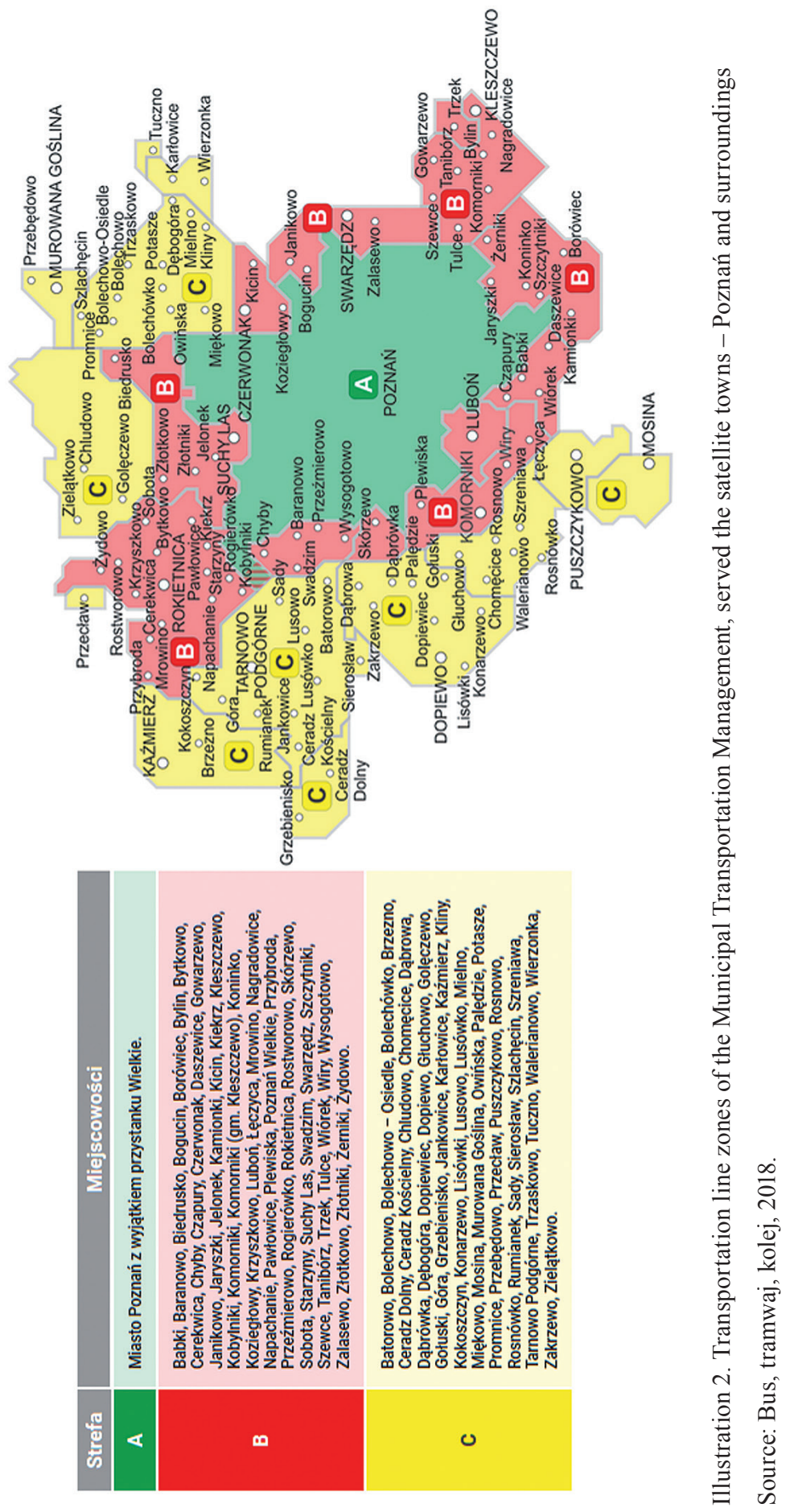



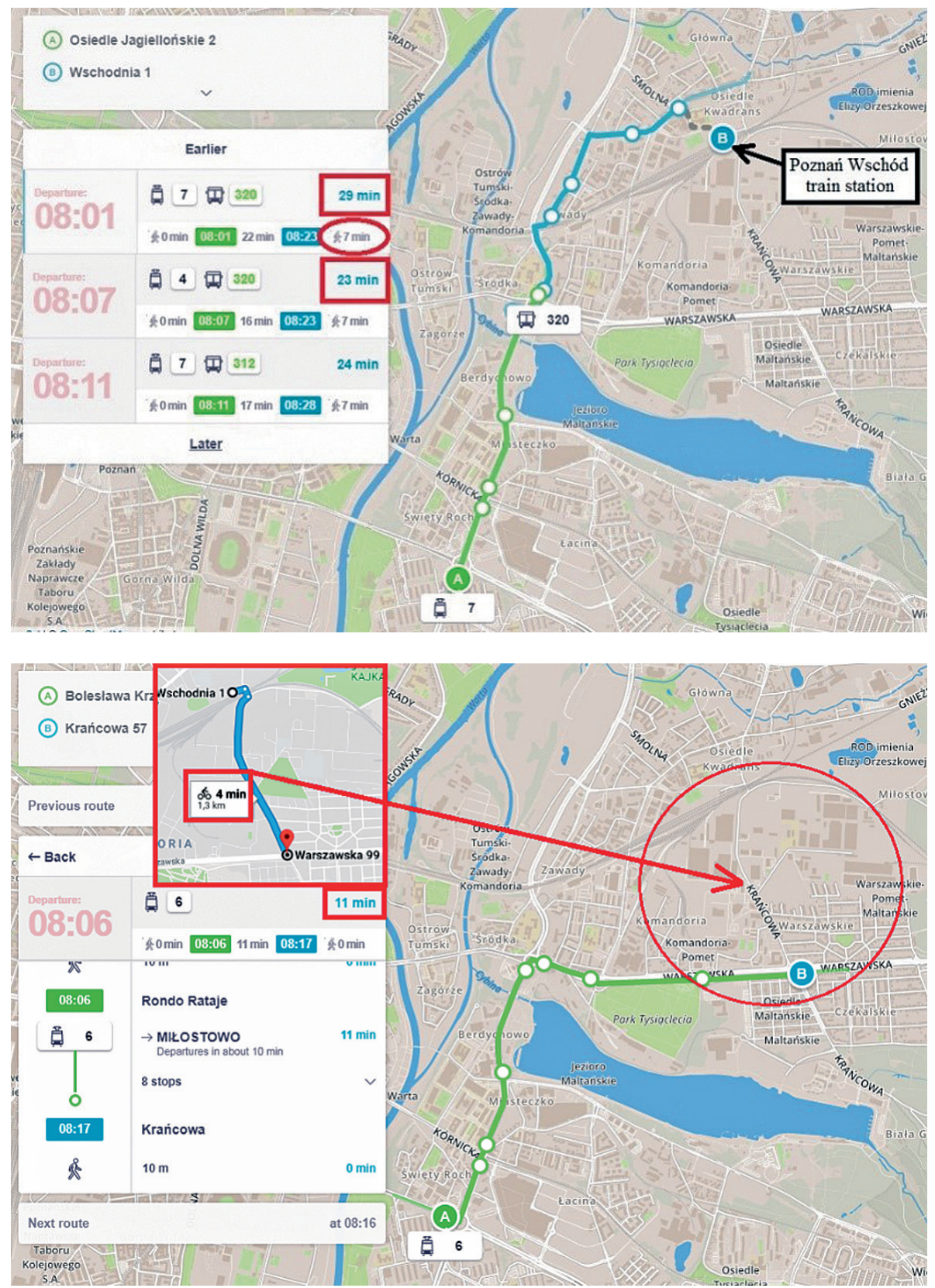

Illustration 3. A case study illustrating an impact of using a city bike in the overall hybrid transport within the city: (a) using only bus and tram transport, (b) inclusion of the bike as an intermediate mean of transport

Source: "Jak dojadę. Poznań". 


\subsection{Mobility on Demand}

The Mobility on Demand (MOD) is a solution similar to the city bike. It relies on renting a car for short periods of time [Federal Transit Administration, 2016].

An expected impact of the MOD system is reducing the demand for parking spaces (cars under MOD could potentially be in constant motion). However, some limitations of this system can be shown. The problem is a distribution of rental points over a given area in such a way, so that access to them does not take longer than to bus/tram stops. Another problem is a need for a sufficient space, where the cars would be available for renting. In the context of cities, there remains the problem of the participation of these vehicles in road traffic, where there is already a lot of traffic.

One of the solutions could be limiting the usage of such cars to some areas only, where there is less traffic, outside of centers of the cities. However, in this case another problem may appear - an uneven demand for travel directions. For example, in the morning there would be a greater demand for travel to the agglomeration center, and in the afternoon greater demand for travel in opposite direction.

\subsection{Autonomous taxis}

This solution is gaining popularity in recent time [Rewolucja $w$ Azji..., 2016], being introduced in some cities, e.g. in Singapore and Tokyo. Such cars, however, do not solve the problem of traffic jams, participating in the road traffic inside cities. When popularized and used on some restricted areas, as proposed above, this solution could solve some problems of the MOD system, for example the one of uneven demand and required renting spots, described above.

The outlined solutions should further develop towards increasing their competitiveness in relation to private and individual transport. Most of them will certainly work well in larger cities (more travelers, shorter distances, high rotation of driving directions, etc.). However, in the case of satellite towns or settlements some modifications are required, as discussed in this work.

\section{Intelligent public transport in the context of small satellite cities}

The ITS may offer solutions, both for the individual and the public transport. In the second case, promoted by sustainable mobility and sustainable urban transport planning [Chamier-Gliszczyński, Krzyżyński, 2011], the term "intelligent" can equally mean intelligent technologies, as well as flexible organizational solutions, that support the implementation of these technologies. 
This paper emphasizes the competitiveness of public transport in relation to the individual transport. In particular, it puts an attention to such solutions, that do not require major interference in spatial planning of the cities. Some of the problems may be overcame by the ITS, especially the aforementioned autonomous vehicles, supported by the V2I communication system [Maile, 2007; Bai, 2013].

\section{I. Toward an autonomous MOD system}

The previously discussed MOD system, limited by its range to selected areas only, may become more efficient, when autonomous cars will be used. Selected advantages are outlined below:

- in contrast to standard MOD approach, autonomous cars constantly could circulate in the city, so there is no need to create a dense network of rental spots; this also solves the described problem of the "first and the last kilometer";

- groups of such cars would be assigned to given districts/extra-urban areas, so as to ensure the possibility of quick access only to the nearest public transport nodes, thus not generating additional traffic in other areas of the city;

- the V2I system could be used to localize vehicles in a given area, in order to minimize travel time and waiting time for a vehicle, as well as possible "empty" journey (without passengers);

- such cars could drive themselves to the battery charging station, assuming an electric drive.

The system could be supported by an on-line application, allowing selecting a route and thus for a reservation a car. Collecting data on a daily usage of such cars on a given area could be used to optimize the system (number of cars in a given area, boundaries of the areas, etc.). To make it possible a system, based on artificial intelligence solutions, may be developed and applied.

The described features can become an important step towards the implementation of a flexible MOD system in such areas, in which it is currently unprofitable and uncomfortable, for example in the context of smaller satellite villages. Such MOD system would be integrated with other public transport means, with the railway system as a framework.

\subsection{Safety aspects}

According to the report by McKinsey, for example, the number of traffic accidents in the United States will fall by $\mathbf{9 0 \%}$, thanks to self-driving cars [BBVA, 2018].

To make this vision happen, autonomous vehicles require comprehensive tests, as they should be able to fully mimic the behavior of the driver. This includes recognizing objects around the vehicle and responding appropriately to 
ensure safe driving. It can be said, that the more complex the environment (the number of visible objects), the more challenging it is for the systems of an autonomous vehicle. In densely populated areas, the environment features a greater variability, while outside these areas (smaller towns) less complexity may be expected. Taking it into account, the author of this paper thinks, that prototype autonomous vehicles could initially be used mainly in the peripheral areas of the cities, for example to quickly bring residents to transport hubs or children to schools. Only after thorough testing, they could be gradually introduced in more dense areas.

\subsection{Intelligent hybrid transportation system for satellite villages and communes}

One of the issues is the way, in which autonomous vehicles should be used in the vicinity of satellite cities. As discussed earlier, for safety reasons, in early stage of development, such vehicles should be allowed on such routes, that will be prepared for this purpose, for example, by the use of the V2I system.

An important parameter are distances on which such vehicles would move when servicing a specific group of residents. The greater the distance, the larger is required number of such vehicles on a given area. A case study for Poznań agglomeration was carried out as an example here. Illustration 4 shows a network of railway lines around Poznań city, as well as satellite villages located along these lines. The villages were selected within a radius of up to $15 \mathrm{~km}$ from particular stations. A selected radius of up to $50 \mathrm{~km}$ from Poznan is consistent with the area of the BTK hybrid transport program described above.

Illustration 5 shows an area comprising the Pobiedziska community described above, as well as the Poznań Wschód station, presented on Illustration 3. The results are shown in the form of "dependent" areas of particular stations. For this purpose, Voronoi diagrams have been used, in which each station is treated as an attractor with its own impact zone. The diagrams were created on the basis of geographic distances between particular villages and corresponding railway stations. In fact, more important than distances counted according to geographical coordinates are the ones, measured along roads, i.e. including natural terrain obstacles. An example case is shown on Illustration 6, for a selected Wronczyn town and the Biskupice Wielkopolskie station. The road distance is in this case $12 \mathrm{~km}$, instead of about $7 \mathrm{~km}$ of geographical distance.

As shown on the Illustrations, the "dependent" areas of particular stations may be relatively wide. In this situation, if there is not enough space for a parking plot directly at a given railway station, one can consider creating a parking or a network of parking lots at some distances from the railway station. Then, autonomous vehicles would operate only on the roads between such lots and the stations, so the parking areas of these vehicles could be smaller in this case. 


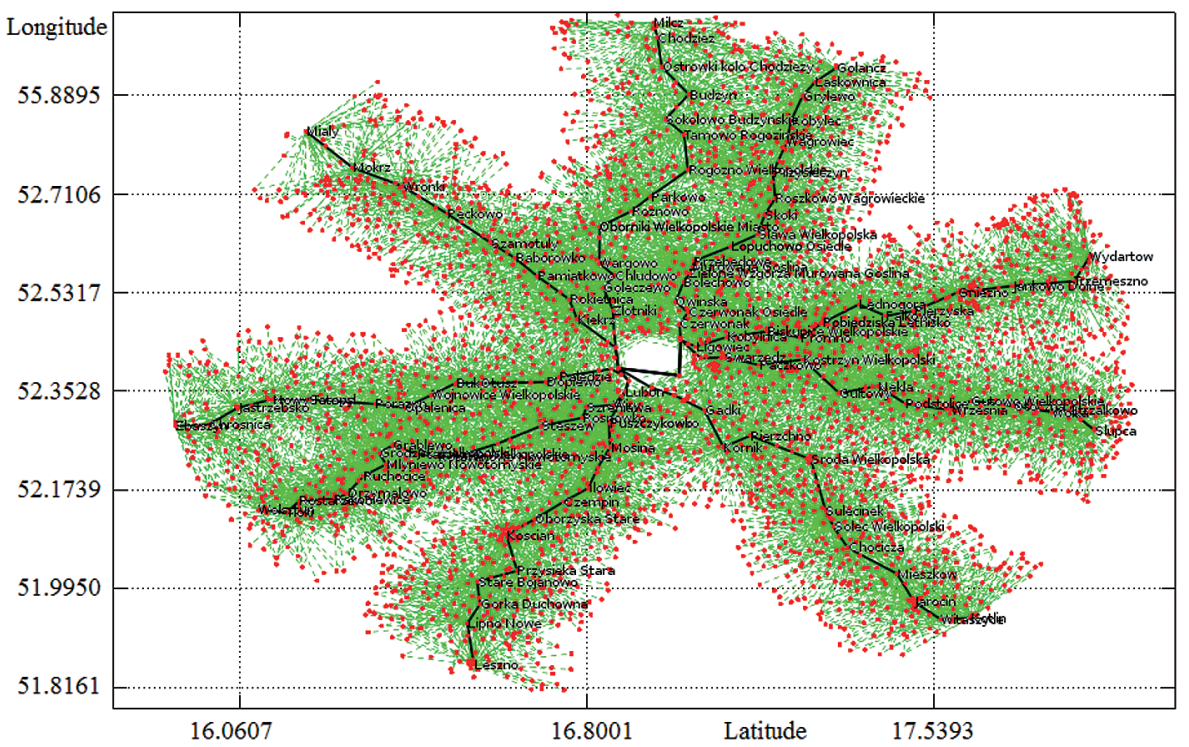

Illustration 4. A diagram showing a net of railway stations near Poznań with selected satellite villages. The shown villages were selected on the basis of geographical distances

Source: author's own work.

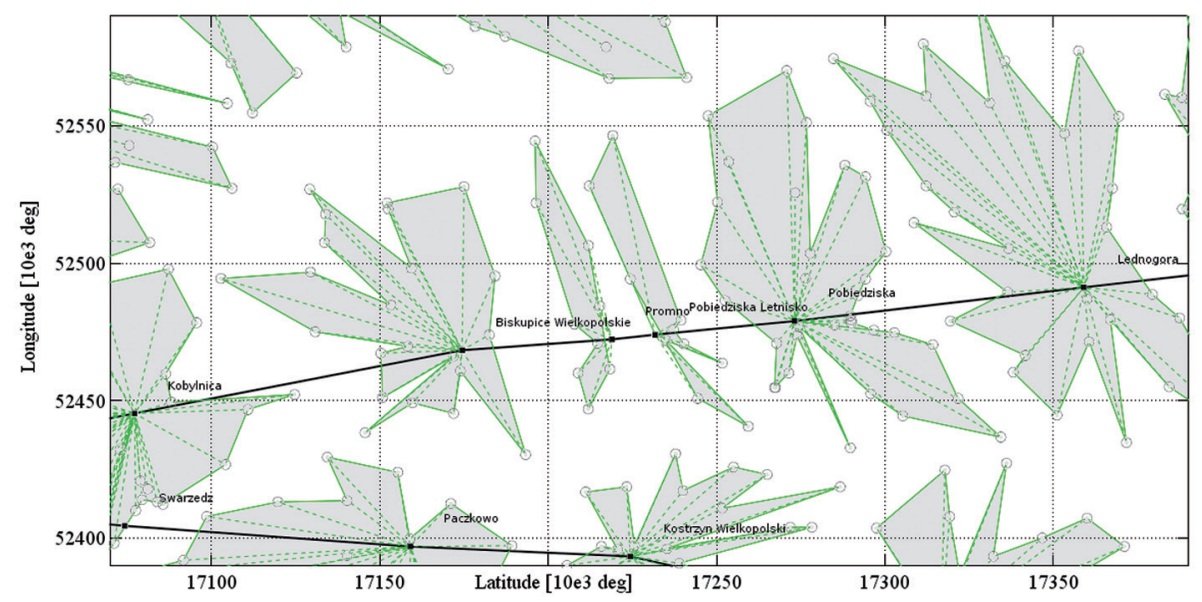

Illustration 5. A case study for a selected train line comprising Pobiedziska commune, presented in the paper. Gray shapes illustrate areas of interest for particular local stations (Voronoi diagram), computed on the basis of geographical coordinates

Source: author's own work. 


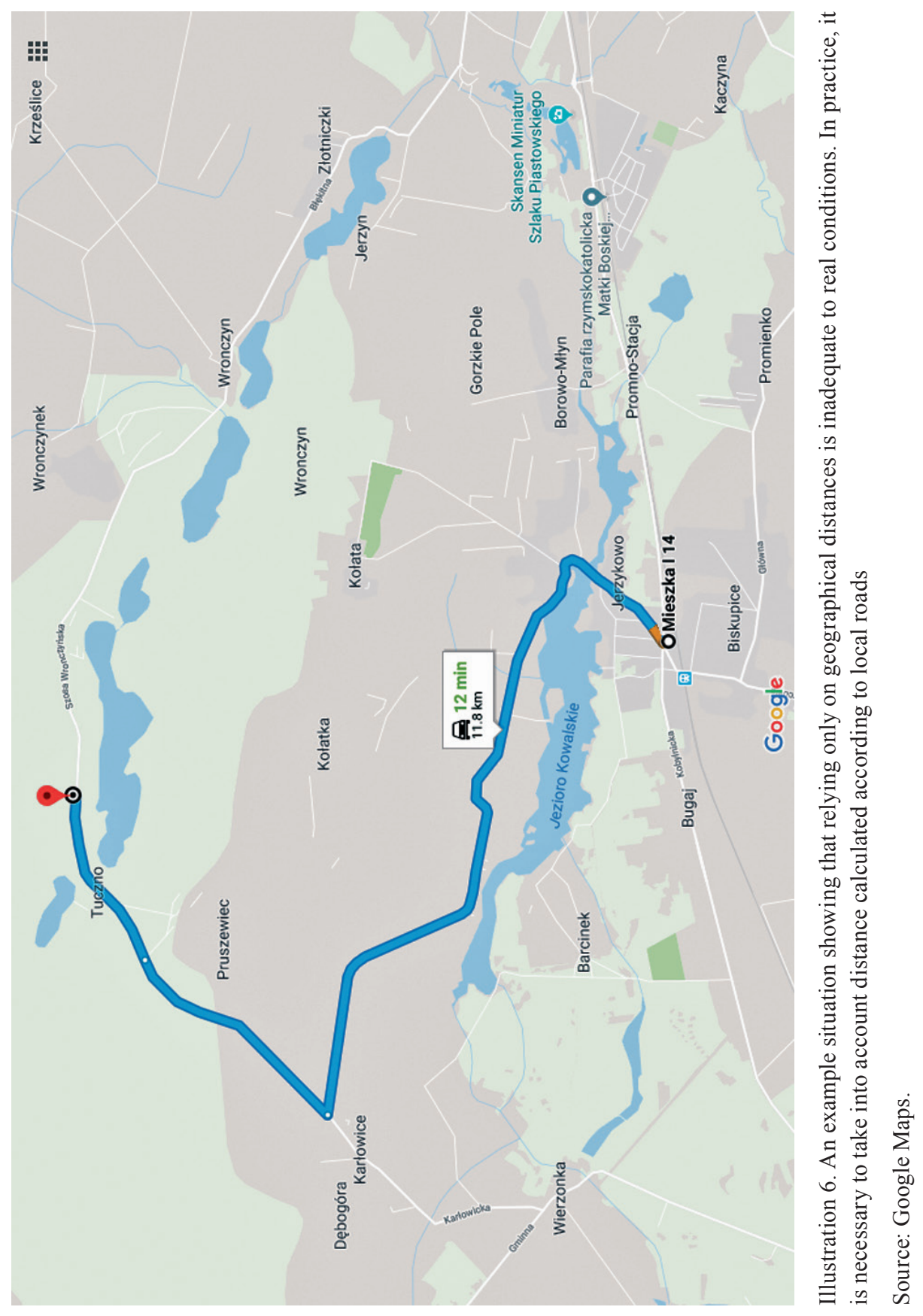




\section{Conclusions}

The paper proposes a way in which modern technologies, especially those in the area of intelligent transportation system (ITS), can be used as a support for public transport in smaller satellite towns more distant from the center of larger urban agglomerations. One of the solutions in a near future may be the development and dissemination of an intelligent public transportation system, which on one hand would offer flexible transport options, but what is important here, would solve the problem of the first and the last kilometer. This could be achieved by using autonomous cars operating in peripherals of the cities.

This paper presents selected advantages of such a system, comparing it with currently used hybrid transportation systems. The required cost does not have to be high, as autonomous vehicles in the municipality's equipment would not need a full-time driver.

\section{References}

Bai S. (2013), US-EU V2V V2I Message Set Standards Collaboration, Honda R\&D Americas, Inc.

BBVA (2018), How Cities Will Change with the Arrival of Self-Driving Cars, https://www.bbva. com/en/how-cities-will-change-arrival-self-driving-cars [accessed: 6 December 2018].

Bus, tramwaj, kolej (2018), Bilet wielu możliwości, http://bustramwajkolej.pl [accessed: 25 January 2018].

Bydgoszcz (2018), Inteligentne systemy transportowe, http://www.bydgoszcz.pl/rozwoj/ smart-city/inteligentne-systemy-transporotwe [accessed: 6 December 2018].

Chamier-Gliszczyński N., Krzyżyński T. (2011), Zrównoważona mobilność w miastach, "Logistyka", 3.

Dąbek A. (2013), Pierwszy/ostatni kilometr w transporcie, “Zarządzanie Innowacyjne w Gospodarce i Biznesie", 2 (17).

Domański T., Kozłowski K. (2017), Mamy informację z pierwszej ręki: Intel potwierdził, że autonomiczne BMW już niebawem trafia do seryjnej produkcji, https://www.spidersweb. pl/2017/06/bmw-inext.html [accessed: 2 February 2018].

Duranton G., Turner M.A. (2016), The Fundamental Law of Road Congestion: Evidence from US Cities, "American Economic Review”, 101 (6).

Federal Transit Administration (2016), Mobility on Demand (MOD) Sandbox Program, https://www.transit.dot.gov/research-innovation/mobility-demand-mod-sandbox-program.html [accessed: 2 November 2017].

GDDKiA (2015), Krajowy System Zarzqdzania Ruchem Drogowym na sieci TEN-T-etap I, https://www.gddkia.gov.pl/pl/a/24079/Krajowy-System-Zarzadzania-Ruchem-Drogowym-na-sieci-TEN-T-etap-I [accessed: 2 February 2018].

Holdsword R. (2018), A Ride on Heathrow's Self-Driving Pods, https://londonist. com/2014/09/a-ride-on-heathrows-self-driving-pods [accessed: 6 December 2018]. 
ISO 37120 (2017), ISO 37120 briefing note: The first ISO International Standard on city indicators, https://www.iso.org/files/live/sites/isoorg/files/archive/pdf/en/ 37120_briefing _ note.pdf [accessed: 2 November 2017].

“Jak dojadę. Poznań", https://jakdojade.pl/poznan [accessed: 6 December 2018].

Jia D., Ngoduy D. (2016), Enhanced Cooperative Car-following Traffic Model with the Combination of V2V and V2I Communication, Elsevier, "Transportation Research. Part B: Methodological", 90.

Koleje Wielkopolskie (2018), Bus-tramwaj-kolej-jeden bilet, http://koleje-wielkopolskie. com.pl/bus-tramwaj-kolej-jeden-bilet [accessed: 25 January 2018].

Korolczuk M. (2015), Zaskakujace wyniki systemu Tristar, Trójmiasto.pl, https://www.trojmiasto.pl/wiadomosci/Zaskakujace-wyniki-systemu-Tristar-n97482.html [accessed: 2 February 2018].

Lehmann S. (2010), Green Urbanism: Formulating a Series of Holistic Principles, "Surveys and Perspectives Integrating Environment \& Society (SAPIENS)", 3 (2).

Maile M. (2007), Vehicle Safety Communications - Applications (VSC-A) Project: Crash Scenarios and Safety Applications, VSC-A Applications_NHTSA - CAMP Comparison v2 document, USDOT.

Metropolia Poznań (2018), http://www.aglomeracja.poznan.pl/aglomeracja/aglomeracja/ news,1141/wezly-przesiadkowe-w-gminie-pobiedziska,122587.html [accessed: 2 December 2018].

Motaa D.R., Takanob M., Tacob P.W.G. (2014), A Method Using Gis Integrated Voronoi Diagrams for Commuter Rail Station Identification: a Case Study From Brasilia (Brazil), XVIII Congreso Panamericano de Ingeniería de Tránsito, Transporte y Logística (PANAM 2014), Elsevier, Procedia - Social and Behavioral Sciences, 162.

Owczarzak Ł., Żak J. (2015), Koncepcja transportu publicznego na żqdanie w oparciu o wykorzystanie samochodów autonomicznych, "Logistyka", 5, https://www.czasopismologistyka.pl/artykuly-naukowe/send/328-artykuly-na-plycie-cd-1/7363-artykul [accessed: 2 December 2018].

Pobiedziska. Moc inspiracji (2018) Komunikacja tematem Powiatowej 17 w Pobiedziskach, http://www.pobiedziska.pl/komunikacja-tematem-powiatowej-17-pobiedziskach [accessed: 6 December 2018].

Rewolucja w Azji. Autonomiczne taksówki wyjechaty na drogi (2016), TVN24 BiS, PAP, http://tvn24bis.pl/moto,99/na-ulice-wyjechaly-pierwsze-na-swiecie-autonomiczne-taksowki,671057.html [accessed: 2 November 2017].

Szymańska D., Grzelak-Kostulska E. (2005), Małe miasta w Polsce - zmiany ludnościowe $i$ funkcjonalne $w$ drugiej polowie $X X$ w., https://repozytorium.umk.pl/bitstream/ handle/item/545/Ma\%C5\%82e\%20miasta\%20w\%20Polsce $\% 20-\% 20$ zmiany $\% 20 \% 20$ DOC230513-004.pdf [accessed: 20 November 2018].

Venkatesh Prasad K., Hodges S., Noble B. (2016), Toyota's Ken Laberteaux Talks about the Road ahead, https://ieeexplore.ieee.org/stamp/stamp.jsp?tp=\&arnumber=7389285 [accessed: 25 January 2018].

Wałkuska K. (2003), Problemy zrównoważonego rozwoju małych miast na przykładzie miasta Wizna [in:] M. Zemło (red.), Małe miasta. Przestrzenie, Stowarzyszenie Collegium Suprasliense Publ., Supraśl. 
Weekend Service (2008-2019), https://stalbert.ca/city/transit/routes-schedules-and-maps/ weekend-service [accessed: 2 December 2018].

Wschodzący Białystok (2018), System zarzqdzania ruchem w Białymstoku, http://szr.bialystok.pl [accessed: 2 February 2018].

Wyszomirski O. (ed.) (2007), Transport miejski. Ekonomika i organizacja, Gdańsk, https:// docplayer.pl/34752334-Transport-miejski-ekonomika-i-organizacja-pod-redakcja-olgierda-wyszomirskiego.html [accessed: 2 December 2018]. 
